This is a peer-reviewed, accepted author manuscript of the following article: Goudouva, G., Loizia, P., Inglezakis, V., \& Zorpas, A. A. (2018). Quarries environmental footprint in the framework of sustainable development: the case study of Milos island. Desalination and Water Treatment, 133, 307-314. https://doi.org/10.5004/dwt.2018.23087

\title{
Quarries Environmental Footprint in the Framework of Sustainable Development. The case study of Milos Island.
}

\section{Grammati Goudouva1, Pantelitsa Loizia, ${ }^{2,3}$, Vasilis Inglezakis ${ }^{4}$, Antonis A. Zorpas ${ }^{2 *}$}

${ }^{1}$ Forest Department Cyclades, Forester, Management and Protection of Environment, P.O.Box 84801, Milos, Cyclades, Greece

${ }^{2}$ Cyprus Open University, Faculty of Pure and Applied Sciences, Environmental Conservation and Management, Laboratory of Chemical Engineering and Engineering Sustainability antonis.zorpas@ouc.ac.cy, antoniszorpas@yahoo.com, Giannou Kranidioti 33, Latsia, 2220, Nicosia, Cyprus.

${ }^{3}$ ENVITECH (Environmental Technology) Ltd, Institute of Environmental Technology and Sustainable Development, Department of Research - Development, P.O.Box 34073, 5309, Paralimni, Cyprus

${ }^{4}$ Nazarbayev University, School of Engineering, Chemical Engineering Department, 53 Kabanbay batyr ave., Astana, Republic of Kazakhstan

*Corresponding author: E-mail: antonis.zorpas@ouc.ac.cy, antoniszorpas@yahoo.com

\begin{abstract}
The installation and operation of a quarry contains complex, difficult and sometimes unsafe processes (such as explosive) that may affect public health as well as the whole environment and the sustainable development in general in the area which guest the quary. This paper focus on the Environmental Footprint (EF) from quarries activities located in the island of Milos (Greece), where Bentonite, Perlite and pozzolan (type 1 and 2) are mined and extracted. Results indicated that energy consumption is consider to be higher for Bentonite than Perlite while Pozzolan presented with limited consumption per $t$ of product. More specific for the production of Bentonite $1.81 \mathrm{l} / \mathrm{t}$ of oil is needed, $6.15 \mathrm{kWh}$ electricity as well as $7.21 \mathrm{~kg}$ of production needs $1 \mathrm{~m}^{2}$ area. Regarding the production of Perlite $2.861 / \mathrm{t}$ of oil is need, $16.38 \mathrm{kWh}$ electricity while $7.43 \mathrm{~kg}$ required $1 \mathrm{~m}^{2}$ production areas. Pozzolan type 1 consumed $0.71 \mathrm{l} / \mathrm{t}$ of oil, 0.87 $\mathrm{kWh}$ electricity and $0.01 \mathrm{~kg}$ explosives and $2 \mathrm{~m}^{2}$ of production area is needed, while for the production of pozzolan type 2, $0.87 \mathrm{l} / \mathrm{t}$ of oil, $0.76 \mathrm{kWh}$ electricity are needed as well as an area of $10 \mathrm{~m}^{2}$ is required. Concerning the waste generation (which mainly includes rock materials) is $0.83 \mathrm{~m}^{3} / \mathrm{t}$ for Bentonite, $0.39 \mathrm{~m}^{3} / \mathrm{t}$ for Perlite while in the cause of pozzolani 1 and 2 are zero due to the fact that both materials are homogenized. Gaseous emissions were calculated as equivalence of $\mathrm{CO}_{2}$ and for the Bentonite was $1.52 \%$, for Perlite was $2.18 \%$ per production $t$ of final product.
\end{abstract}

Keywords: quarries, environmental footprint, greenhouses gas emissions, ecological footprint, carbon footprint, mining activities.

\section{Introduction}

Quarry processes contain complex procedures that may affect several environmental parameters such as energy, carbon dioxide emissions, waste production, lost of landscape etc. As a definition quarry reflect an area which excavations take place aiming to detect and mining natural resources [1]. The usual process may include mining, transportation of the raw materials from the mining area for further treatment, milling, crushing, washing, drying, sieving, 
temporary storage and then loading on a tracks or ships $[2,3]$. Additionally, the lifetime of a quarry, mostly depends on the nature of the stocks, local situations, the market and the local conditions $[4,5]$. The mining process demands significant amount of energy sources in several steps of the production, producing at the same time carbon dioxides, dust and waste.

The global community has implemented innovative techniques along with a wide range of environmental legislations, in order to reduce the pollution of air, water, soil and general environmental degradation [6]. However, many challenges remain and must be tackled together and in a controlled way [7] using a common methodological approach to introduced the effectiveness of natural resources and benchmark of the environmental performance of products, services and business, based on a systematic assessment of environmental impacts throughout the life cycle [8]. The term "Environmental Footprint" (EF) (Environmental or Ecological Footprint), was mentioned during 90s by Mathis Wackernagel and William Rees [9, 10]. EF stated in an indicator (qualitative), which measures the extent required for the disposal of waste generated during the production of the required resources [9]. Moreover, according to Ryan [11], EF is also used to estimate the impact at national and regional level as well as in any enterprises [8]. EF also is an innovative technique of calculating the ecological dimension of sustainability [12]. Also, EF is a method that can be used to evaluate the availability of natural resources and the degree to which production and consumption have an impact on them [13]. Wackernagel and Yount [12] declared as Ecological Footprint (Environmental Footprint) of an organization or an enterprise the entire greenhouse gas emissions (GHG) caused by the organization. EF is often calculated in terms of kilograms of carbon dioxide $\left(\mathrm{kg} \mathrm{CO}_{2}\right)$, or its equivalent in other greenhouse gases emitted and is therefore referred to as a carbon footprint $\left(\mathrm{CO}_{2}\right.$ Footprint) [12, 13]. Carbon footprint is defined according to ISO/TS 14067:2013 Technical committee [14] as a measure of the climate change impact of the product where all the greenhouse gas emissions emitted during the product life cycle are considered. It is very important that, nowadays, several international standards exist for determining and certificating the carbon footprint in any organization as well as in any processes, such as ISO 14064-1 and GHG Protocol [6]. It is remarkable, that an Environmental Management System (EMS) can be applied in any kind of organization aiming to improve their environmental performances while at the same time set specific and measurables targets for continual improvement $[15,16,17$, $18,19]$. Solving environmental problems as a result of growth of business and the broader economic issues, is only possible by applying a systematic approach like EMS and the search for new methods of more efficient operational and state level in order to ensure economic and simultaneously eco stability [20]. The implementation of EMS from any organizations could be a sustainable tool in order to determine and control their environmental aspects and take measures to minimize their adverse impact on the environment. Hence, EMS, main objectives are the prevention of environmental problems, the development of environmental awareness and improving quality of life $[18,21]$.

Mining industry has declared its commitment for sustainable development and recognizes the need to control environmental performance, focus on cleaner technologies and efficient use of resources [22].. EF could serve as a tool to quantify and measure the environmental impact caused by the operation of an organization or business [23]. Knowing the EF, scientists or consultants can help the organization or the company to design a specific strategy to reduce the adverse impact of its operations on the environment [10]. This strategy can be integrated through innovative applications, technological development elements, improved procedures for production management and services, data collection, carbon emissions and creating indicators, new approaches to consumption, waste management, etc. [22]. 
To the best of our knowledge, there are limited available date regarding the EF from mining sectors and this paper focus on the determination of $\mathrm{EF}$ in quarries activities from Milos Island (Greece) using the EMS of ISO 14064.

\section{Material and Methods}

\subsection{Description of the Area}

The island of Milos (volcanic origin and hilly island) was chosen for the determination of EF (Figure 1). Milos belong to Cyclades, Greece, with subtropical climates [3] as the average precipitation does not exceed $500 \mathrm{~mm}$.

\section{[Figure 1]}

Because of extensive volcanic activity and phenomena such as intense geothermal activity and tectonic modification, products of economic interest (in the eastern region of the island) have been created (Bentonite, Perlites, pozzolan etc.) and cover a total area of $20 \mathrm{~km}^{2}$ (Figure 2). Morphologically, the island it is characterized as mountainous. In the natural environment according to Goudouva and Zorpas, [3], the island is dominated by bushy vegetation, with arboreal vegetation found only in suitable habitats, near small streams and slopes of more high mountains. The mining activity on the island is intense because of the large deposits that occur in the region and the mining of the minerals include the method of opencast with righteous consecutive open pit stages. When this method is implemented levels are opened, which start upstream and descend down to the bare deposit or learned to exploit the rock. Initially, there is removal of vegetation and then removing of the topsoil, which in many cases is stored to be reused in the process of restoration of the mining area. Then the overlying mineral materials are removed and follows extraction of the mineral. The extraction of the mineral is done mainly mechanically using promoters and occasionally with limited use of explosives. The mining area varies from 3-8 $\mathrm{m}$ height and $6 \mathrm{~m}$ width.

\section{[Figure 2]}

\subsection{EF determination using ISO 14064}

To identify and quantify EF of quarries operations the requirements of ISO 14064 were followed [13, 24]. ISO 14064 indicates the requirements and the instructions for inventory, quantification and reporting of GHG emissions including carbon dioxide $\left(\mathrm{CO}_{2}\right)$, methane $\left(\mathrm{CH}_{4}\right)$, nitrous oxide $\left(\mathrm{NO}_{2}\right)$, hydrofluorocarbons (HFC), perfluorocarbons (PFC) and sulfur hexafluoride (SF6) [13]. These instructions provide a basic structure in which reliable and consistent controls are in force. Furthermore, the standard provides policy-makers with a set of well-organized practices to reduce GHG emissions [10]. The standard essentially defines three key aspects related to the development of the greenhouse effect. These aspects include establishing inventory levels, the quantification of GHGs and reporting [24]. A key objective of the process was to create a rigorous technical product that could be applied to a company regardless of the current policy of a country on tackling climate change [7]. The standard includes essential principles to ensure the validity of the results. These principles include relevance, completeness, coherence, accuracy and transparency. During the process of assessing the EF the following steps [13] were established: (i) identify specific sources of emissions, (ii) the selection of quantification methodology, (iii) data collection, (iv) quantifying emissions for each source, (v) determine total emissions. A guide to the organization of private 
and public sector, as well as a foundation for policy makers and development programs, aimed at tackling global environmental challenges of climate change [13. 25]. ISO 14064 [24] has four main steps in order to determined and evaluated EF and includes: (i) defining the objectives and context of the evaluation, (ii) census data analysis, (iii) impact assessment based in Life Cycle Analysis (LCA) or other methods (iv) interpretation of the results. To assess EF impact assessment according to LCA is needed to define the scope of the study, the boundaries of the system, the time and the geographical boundaries as well as the necessary data to be used. The Scope of the system includes five quarries (Figure 3), in which Bentonite, Perlite and pozzolan were mining (covering the geographical limits of the system). The functional unit is defined as a market producer production per $t$, were the survey data was examined for three years (covering the time limits of the system) of operation. Hence, all the data needed for this research had been collected from the quarrying companies through a questionnaire and survey audit. Those data include the amount of energy used for the operation of the quarry, the type of energy used, air emissions and amounts of waste produced. The statistical analysis was caring out using the Statistical Package for Social Sciences (SPSS V.22.0).

\section{Results and Discussions}

From the survey audit, Bentonite mining activities include the following steps: revelation mining, transfer from the mining area to be treated, milling (during which breakage adding soda and drying), storage and finally loading in the ships to be transferred into the market. For the production of Perlite, the processing includes, the following steps were followed: revelation mining, transfer from the mining area to be treated, milling, during which crushing, drying and sieving, storage, loading on ships. Finally, the production process of the pozzolan encompasses the following steps: mining, internal transfer, breakage when breaking and sifting is performed, storage, loading on ships.

Through the survey audit it was also find out that all the examined mining companies has certified (from several certification body) EMS in place in the framework of ISO 14001. Within the EMS, the mining industries has developed specific programs in order to maintain and control their activities which has diverse impact on the environment. Typically, all of the mining companies has written procedures in place which maintain and control the consumption of energy, their emissions $\left(\mathrm{CO}_{2}\right)$ on the environment, the water consumption, the waste production. For example, the water footprint (during those mining activities) as indicated by Goudouva and Zorpas [3] was $0.048 \mathrm{~m}^{3} / \mathrm{t}$ for Bentonite, $0.07 \mathrm{~m}^{3} / \mathrm{t}$ for perlit, $0.03 \mathrm{~m}^{3} / \mathrm{t}$ and $0.18 \mathrm{~m}^{3} / \mathrm{t}$ for the pozzolan type 1 and type 2 respectively. Additionally, through the implementation of the EMS the industries developed their environmental policy and set specific objectives and targets to minimized their environmental impacts [16]. Through the commitment that indicated in their policy, organizations aim to improve their environmental performance [21].

The average production (mean values of the last three years) of the minerals Bentonite, Perlite and pozzolan extracted from quarries presented in Fig. 4. Bentonite production is up to $1.05 \pm 0.13$ million of $t / y$ followed by Perlite that the average production is $0.44 \pm 0.52$ million of $\mathrm{t} / \mathrm{y}$ and pozzolan (type 1 and 2 ) average production is $0.109 \pm 0.21$ million of $\mathrm{t} / \mathrm{y}$.

\section{[Figure 4]}

Each mining process needs significant amount of energy (Table 1, 2, 3, 4). Regarding the mining process of Bentonite (Table 1) are needed $964823.30 \pm 95870.341 / y$ of oil. Oil is needed 
also for the transportation step, which the average amount is $612427 \pm 441740.11 / \mathrm{y}$. For the milling and distribution process, the industry used mazut $(7539333 \pm 351420.5 \mathrm{~kg} / \mathrm{y})$ and electric powder $(6113683 \pm 457439.5 \mathrm{kWh} / \mathrm{y})$. Electricity also is needed when the mineral is loaded in the ships and the average consumption was $331141.7 \pm 29788.63 \mathrm{kWh} / \mathrm{y}$. The energy consumption in the case of Perlite presents similarities with the energy consumption in the case of Bentonite. More specific, the liquid fuels (oil) that are needed (Table 2) for the mining and transportation process is $643216.3 \pm 63913.191 / \mathrm{y}$ and $613661.3 \pm 62353.93$ respectively. For the milling and distribution process, the industry used also mazut and the consumption was $3273333 \pm 128484.8 \mathrm{~kg} / \mathrm{y}$ while the electric powder was $7017333 \pm 531489.7 \mathrm{kWh} / \mathrm{y}$. Electricity also is needed when the mineral is loaded in the ships and the average consumption was $220762 \pm 19858.58 \mathrm{kWh} / \mathrm{y}$. In the case of Pozolan 1, beside liquid fuels and electricity, explosives are also needed. Explosive $(3700 \mathrm{~kg}$ ) are used in the mining process as its easier to breakdown the rocks (with this process mining industries saves time and fuels, but produced dust).

\section{[Table 1]}

\section{[Table 2]}

\section{[Table 3]}

\section{[Table 4]}

Figure 5, presents the waste generation per mineral production while, Fig. 6 indicates the concentrations of dust for each mining stage. Bentonite disposed of in extracting greater amounts of sterile materials, compared with Perlite and pozzolan type 1 and 2. Concerning the waste generation (which is consist from rocks material) is $0.83 \pm 0.25 \mathrm{~m}^{3} / \mathrm{n}$ for Bentonite, $0.39 \pm 0.19 \mathrm{~m}^{3} / \mathrm{t}$ for Perlite (total needed area is equal with $1 \mathrm{~m}^{2}$ ) while in the cause of pozzolan 1 and 2 are zero due to the fact that both materials are homogenized. From the Tables 1,2,3 and 4 it is observed that the production of oil, which is considered as hazardous waste [26] (according to the $2000 / 532 / \mathrm{EC}$ ), is $0.0060 \pm 0.0026 \mathrm{~kg} / \mathrm{t}$ for Bentonite, $0.009 \pm 0.004 \mathrm{~kg} / \mathrm{t}$ for Perlite, $0.00064 \pm 0.0011 \mathrm{~kg} / \mathrm{t}$ and $0.0063 \pm 0.0109 \mathrm{~kg} / \mathrm{t}$ for the pozolani1 and the pozolani 2 . It's important to know that the sterile materials are used in the recovery process, while the remaining is collected for recycling. Tires from track lories (Table 1 and 2) are produced s and is $881.6 \pm 69.69 \mathrm{~kg} / \mathrm{y}$ in the case of Bentonite, while for Perlites is up to $596.6 \pm 51.85 \mathrm{~kg} / \mathrm{y}$.

\section{[Figure 5]}

\section{[Figure 6]}

Significant amount of dust emissions appears in open-pit quarries as indicated by Sairanen, et. al., [27]. Comparing dust concentrations for each unit per production process, based in Figure 6 , lower concentrations occur during the mining process, in which pozzolan 2 gives highest values and pozzolan 1 gives the lowest values. During the processing stage, Perlite presents high and significant concentration of dust than other minerals, due to the low material moisture. Pozzolan 1 shows the lowest concentrations of dust during processing. In the process of loading the materials on ships directed to the market, pozzolan 2 presents higher values $(0.86 \pm 0.36$ $\mathrm{mg} / \mathrm{m}^{3}$ ) than the other minerals. Moreover, the higher emission of dust in reverse series is $16.09 \pm 10.33 \mathrm{mg} / \mathrm{m}^{3}$ for the production of Perlite, $6.59 \pm 5.14 \mathrm{mg} / \mathrm{m}^{3}$ for the production of Bentonite, while Pozolan 2 is $1.23 \pm 1.21 \mathrm{mg} / \mathrm{m}^{3}$ and for Pozolan 1 is $0.35 \pm 0.29 \mathrm{mg} / \mathrm{m}^{3}$. Usually, 
the compositional analysis of dust around quarries presents similar characteristics with the mineralogical properties of the bedrock [28], but it is not identical since different minerals break down or are removed at different rates due to the quarrying processes [29]. Studies indicate that in open pit quarries the concentration of dust varies from $100-40000 \mu \mathrm{g} / \mathrm{m}^{3}$ for crushing process while for drilling process the concentration may be up to $110000 \mu \mathrm{g} / \mathrm{m}^{3}[28,29]$. Dust exposure can be related with serious health risks beside environmental effects [29] as some epidemiological studies have reported adverse health effects of exposure airborne particulate matter [30]. Also, other studies mentioned that exposure to quarry dust, harmful effect on lung function may exist $[31,32]$ as well as on pneumoconiosis, hard metal disease, allergies, cancer etc, [33].

As indicated in Tables 1,2,3, and 4 during the mining of all the materials significant concentrations of $\mathrm{COx}, \mathrm{NOx}, \mathrm{SO}_{2}$ are realized into the air beside the dust. $\mathrm{NOx}$ is presented up to $99.48 \pm 17.86 \mathrm{mg} / \mathrm{Nm}^{3}$ in the case of Bentonite and with the concentration of NO to be up $96.83 \pm 16.31 \mathrm{mg} / \mathrm{Nm}^{3}$. In the case of Perlite, the concentration of NOx is $131.91 \pm 66.53 \mathrm{mg} / \mathrm{Nm}^{3}$ while the concentration of $\mathrm{NO}$ is $126.81 \pm 63.28 \mathrm{mg} / \mathrm{Nm}^{3} . \mathrm{SO}_{2}$ emissions were $0.85 \pm 0.73$ $\mathrm{mg} / \mathrm{Nm}^{3}$ for the production of Perlite and $5.31 \pm 6.72 \mathrm{mg} / \mathrm{Nm}^{3}$ for the production of Bentonite. In the case of Bentonite $\mathrm{CO}_{2}$ emissions was $1.52 \pm 0.31 \%$ and the $\mathrm{CO}$ was $31.38 \pm 28.66 \%$, while in the case of Perlite the emissions of $\mathrm{CO}_{2}$ and $\mathrm{CO}$ were $2.18 \pm 0.67 \%$ and $23.30 \pm 14.41 \%$ respectively.

During the evaluation of EF, special attention should be given to the changes that occur to landuse as those are metabolized. Quarries and mining activities worldwide has significant impact to the land use [34, 35]. The quarrying areas suffer and extensive land use change and the mining companies received pressure from the Authorities to restored the area [36]. In our case a large percentage of the mining area was originally grassland and forest type. It is estimated (from the survey audit) that the annual loss of forests land from anthropogenic effects (quarries, road construction, etc.) and land use conversion, contribute up to $20 \%$ of the total global greenhouse gas emissions. The IPCC (Intergovernmental Panel on Climate Change) has published a methodology to calculate the emissions from land use changes in circumstances (for example from forest areas in quarries or farms), but the guidance is designed for greenhouse gas inventories in national level and not at product level.

The life of a quarry depends basically on the nature of the stocks and the local conditions [4]. The operation of a mining entails the creation of steps, excavations, deposits, roads and other interventions [37] which needs energy, producing at the same time several kinds of waste and emission to the air. In general, the adverse consequences arising during the stages of extracting the mineral, the transportation, the processing and disposal and dispersion in the environment of each waste type. Within the framework of sustainable development, the adoption of EMS is considered essential for the control of environmental parameters of a business $[15,18,38]$ and furthermore for quarry activities [22]. Additionally, it is an essential prerequisite for any business to include the environment in the long-term development planning [39].

\section{Conclusions}

Generally, the operation of a quarry is a long-term process that requires time and adequate planning. Installing a quarry is not subject to rational choice or planning processes and the locations of mineral deposits are specific and determine the final design, location and size of the business. Therefore, mining activities above the surface of the quarry brought several radical changes in the environment than any other human activity which has adverse effects on the 
environment. EMS can be a sustainable tool for any type of organization in order to maintain and control their adverse impact on the environment in comparison with the EF. Knowing the EF scientists and consultants can help any type of organization to design and implement a specific strategy in order to reduce the adverse impact of its operations on the environment. To ensure the sustainability of the mining sector must be a systematic and continual approach to improve their environmental performance in order to maintain economic growth simultaneously with ecological stability. The findings from this research could be very useful for policy makers, local and regional authorities in order to push the owners of the quarries for continual improvement recording their impacts on the environment. It is clear from our research that the main issues from the mining activities is the metabolism of the areas as well the production of dust while the energy consumption is also a crucial point. Moreover, all those mining companies must implement more sustainable production practices in order to be able to reduced their adverse impact on the environment, through a holistic life cycle analysis.

\section{References}

[1]. Cubukcu, A., Kaya, E., Ozyaral, O., (2012). Environments problems caused by cebeci aggregate quarries and rehabilitation works. 12th International Multidisciplinary Scientific GeoConference and EXPO - Modern Management of Mine Producing, Geology and Environmental Protection, SGEM 2012. 5 (2012) 337-345

[2]. Hu R., Liu J., Zhai M., (2010). A Roadmap for Scientific \& Technological Development of Solid Mineral Resources in China to 2050. Mineral Resources Science in China: A Roadmap to 2050. Chapter 2, 11-82 Springer.

[3]. Goudouva, G.T., Zorpas, A.A., (2017). Water Footprint determination by quarry operation in island regions, Desalination and Water Treatment, In Press doi: 10.5004/dwt.2017.20814

[4]. Sinha, R., Pandey, D.K., Sinha, A.K., (2000). Mining and the environment: a case study from Bijolia quarrying site in Rajasthan, India. Environmentalist. 20(3): 195-203.

[5]. Tillotson, M., Liu, J., Guan, D., Wu, P., Zhao, X., Zhang, G., Pfister, S., Pahlow, M., (2014). Water Footprint Symposium: Where next for water footprint and water assessment methodology?. Int. J. Life Cycle Assess.. 19(8): 1561-1565.

[6]. Diaz, E., Fernandez, J., Ordonez, S., Cantob, N., Gonzalez, A., (2012). Carbon and ecological footprints as tools for evaluating the environmental impact of coal mine ventilation air. Ecological Indicators, 18: 126-130.

[7]. Galli, A., Wiedmannb, T., Ercinc, E., Knoblauchd, D., Ewinge, B., Giljumf, S., (2011). Integrating Ecological, Carbon and Water footprint into a "Footprint Family" of indicators: Definition and role in tracking human pressure on the planet. Ecological Indicators. 16: 100-112.

[8]. Venetoulis, J., Talberth, J., (2008). Refining the ecological footprint». Environment, Development and Sustainability. 10: 441-469.

[9]. Pandey, D., Agrawal, M., Pandey, J.S., (2011). Carbon footprint: current methods of estimation. Environmental Monitoring and Assessment. 178 (1-4): 135-160.

[10]. Palletier, N., Allacker, K., Pant, R., Manfredi, S., (2014). The European Commission Organisation Environmental Footprint method: comparison with other methods, and rationales for key requirements. The International Journal of Life Cycle Assessment. 19 (2): 387-404.

[11]. Ryan B., (2004). Ecological footprint analysis: An Irish rural study. Irish Geography. 37(2): 223-235.

[12]. Wackernagel, M., Yount, J.D., (2000). Footprints for sustainability: The next steps. Environment, Development and Sustainability. 2(1): 23-44. 
[13]. Wintergreen J., Delaney T., (2009). ISO 14064 International Standard for GHG Emission Inventories and Verification

[14]. ISO/TS 14067:2013, 5.15.2013. Greenhouse gases e carbon footprint of products e requirements and guidelines for quantification and communication. 1st ed. Technical Specification

[15]. Chavan, M., (2005), An appraisal of environment management systems: a competitive advantage for small businesses, Management of Environmental Quality: An International Journal, 16(5): 444-463.

[16]. Testa, F., Rizzi, F., Daddi, T., Gusmerotti, M.N., Frey, M., Iraldo, F., (2014). EMAS and ISO 14001: the differences in effectively improving environmental performance. $\mathrm{J}$ Clean Prod 68:165-173

[17]. Voukkali, I., Loizia, P., (2015) Policies and Legislation. In: Sustainability Behind Sustainability, Eds A.A.Zorpas. Nova Science Publishers Inc, pp 7-16

[18]. Daddi, T., Testa, F., Frey, M., Iraldo, F., (2016). Exploring the link between institutional pressures and environmental management systems effectiveness: an empirical study. J Environ Manage 183(3):647-656

[19]. Daddi, T., Frey, M., De Giacomo, M.R., Iraldo, F., Testa, F., (2015). Macro-economic and development indexes and ISO14001 certificates: a cross national analysis. J Clean Prod 108:1239-1248.

[20]. Tambovceva, T., Geipele, I., (2011). Environmental management systems experience among latvian construction companies. Technological and Economic Development of Economy. 17(4): 595-610.

[21]. Voukkali, I., Loizia, P., Mihaela-Pociovalisteanu, D., Zorpas, A.A., (2017) Barriers and difficulties concerning the implementation of an Environmental Management System in a Bakery-Confectionary industry in Cyprus for 8 years, Environmental Process, 4(1), pp263-275, DOI10.1007/s40710-017-0242-y

[22]. Brent G., (2011). Quantifying eco-efficiency within life cycle management using a process model of strip coal mining. International Journal of Mining, Reclamation and Environment. 25 (3) 258-273.

[23]. IES, (2011), European Commission Institute for Environment and Sustainability (IES). Analysis of existing Environmental Footprint methodologies for products and organizations: Recommendations, Rationale and Alignment. Joint Research Center. Italy.

[24]. International Organization for Standardization, (2006). «ISO 14064». Geneva Switzerland.

[25]. Finkbeiner, M., (2014). The International Standards as the Constitution of Life Cycle Assessment: The ISO 14040 Series and its Offspring. Background and Future Prospects in Life Cycle Assessment. LCA Compendium - The Complete World of Life Cycle Assessment. Chapter 3, 85-104 Springer.

[26]. Commission Decision, (2000). Commission Decision on 3 of may replacing Decision 94/3/EC establishing a list of wastes pursuant to Article 1(a) of Council Directive 75/442/EEC on waste and Council Decision 94/904/EC establishing a list of hazardous waste pursuant to Article 1(4) of Council Directive 91/689/EEC on hazardous, http://eur-

lex.europa.eu/LexUriServ/LexUriServ.do?uri=CONSLEG:2000D0532:20020101:EN: PDF (accessed on july 2016)

[27]. Sairanen, M., Rinne, M., Selonen, O., (2017). A review of dust emission dispersion in rock agreegate and natural stone quarries. International Journal of Mining, reclamation and environment, $2017 \mathrm{http} / / / \mathrm{dx}$.doi.org/10.1080/17480930.2016.1271385 
[28]. Chang, C.T., (2004) Assessment of influential range and characteristics of fugitive dust in limestone extraction process, J. Air Waste Manage. Assoc. 54(2): 141-148.

[29]. Petavratzi, E., Kingman, S.W., Lowndes, I. (2005). Particulates from mining operations: A review of sources, effects and regulations, Miner. Eng. 18:1183-1199.

[30]. Iii, C.A. (2007). Pope, mortality effects of longer term exposure to fine particulate air pollution; review of recent epidemiological evidence, Inhal. Toxicol. 19(1), 33-38.

[31]. Vinod, N., Swarna, L., Mahesh, M., (2012). Morbidity profile of stone crusher workers with special reference to respiratory morbidity - A cross sectional study, Nat. J. Community Med. 3(3): 368-371.

[32]. Draid, M.M., Ben-Elhaj, K.M., Ali, A.M., Schmid, K.K., Gibbs, S.G. (2015). Lung function impact from working in the pre-revolution libyan quarry industry, Int. J. Environ. Res. Public Health, 12: 5006-5012.

[33]. World Health Organization, Hazard Prevention and Control in the Work Environment: Airborne Dust, World Health Organization, Switzerland, WHO/SDE/OEH/99.14. 1999, pp 1-31. (April 2017) Available at http://www.who.int/ occupational_health/publications/en/oehairbornedust3.pdf

[34]. Nakajima, K., Nansai, K., Matsubae, K., Tomita, M., Takayanagi, W., Nagasaka, T., (2017).Global land-use change hidden behind nickel consumption Science of the Total Environment. 586: 730-737.

[35]. Wadood Moomen, A., (2017). Strategies for managing large-scale mining sector land use conflicts in the global south. Resources Policy. 51: 85-93

[36]. Meuser, H., (2013). Rehabilitation of Soils in Mining and Raw Material Extraction Areas. Soil Remediation and Rehabilitation Environmental Pollution. 23: 37-126.

[37]. Macicasan, V., Muntean, L., Rosian, G., Malos, C., Mihaiescu, R., Baciu N., (2013). An integrated geomorphological approach for quarry rehabilitation (Aghires mining area, Romania). Carpathian Journal of Earth and Environmental Sciences. 8 (3): 187198.

[38]. Proto, M., Malandrino, O., Supino S., (2013). The Integration of Quality Management and Environmental Management Systems. Product-Oriented Environmental Management Systems (POEMS). Chapter 2: 29-53 Springer.

[39]. Tole L., Koop G., (2013). Estimating the impact on efficiency of the adoption of a voluntary environmental standard: an empirical study of the global copper mining industry. 39: 35-45. 


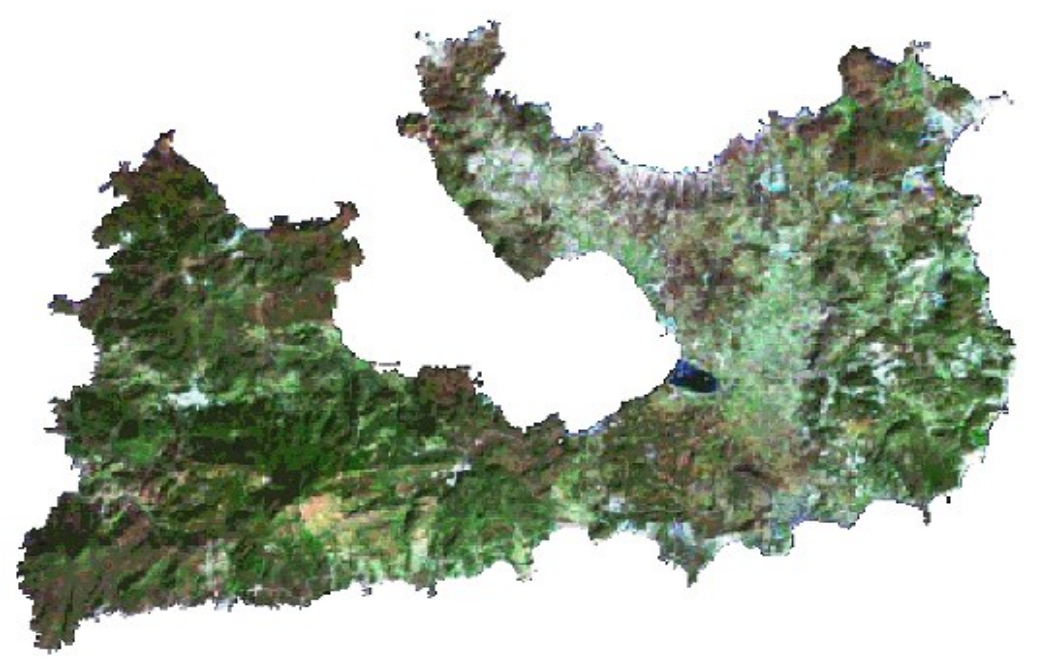

Figure 1: Satellite image of Milos. (Source: QGIS, unit $1 \mathrm{~cm}: 1 \mathrm{~km}$ ).

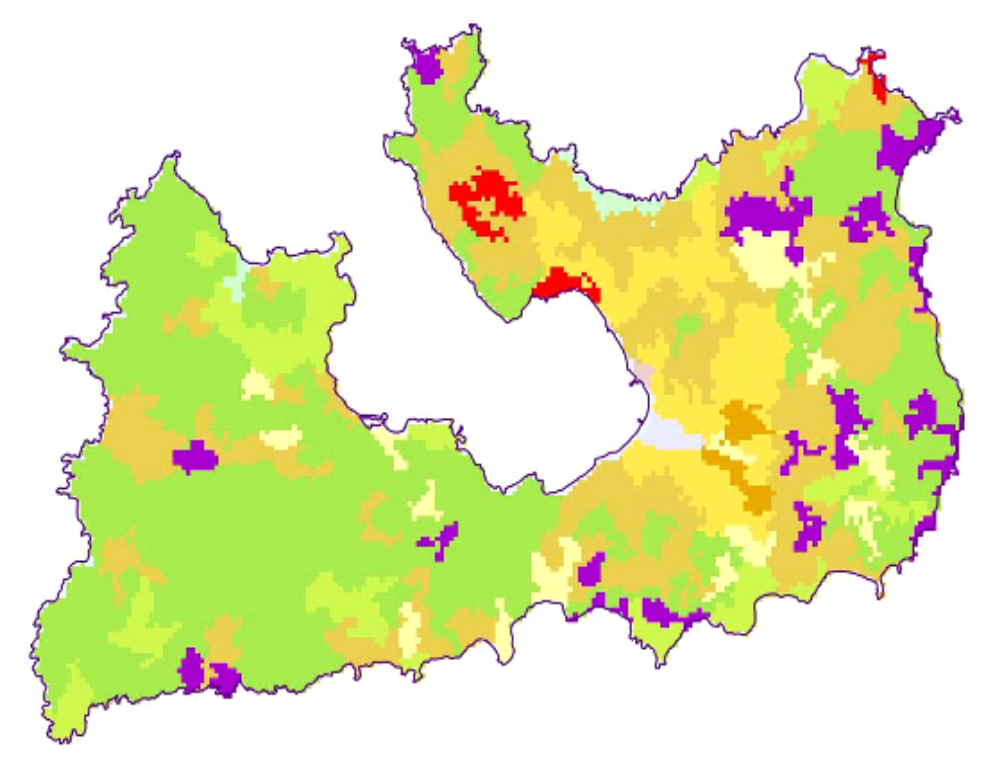

Quarries

Communities-Villages

Forest areas

Agricultural land

Figure 2: Map covers land use base of Corine classification system.

(Source: QGIS unit $1 \mathrm{~cm}: 1 \mathrm{~km}$ ) 


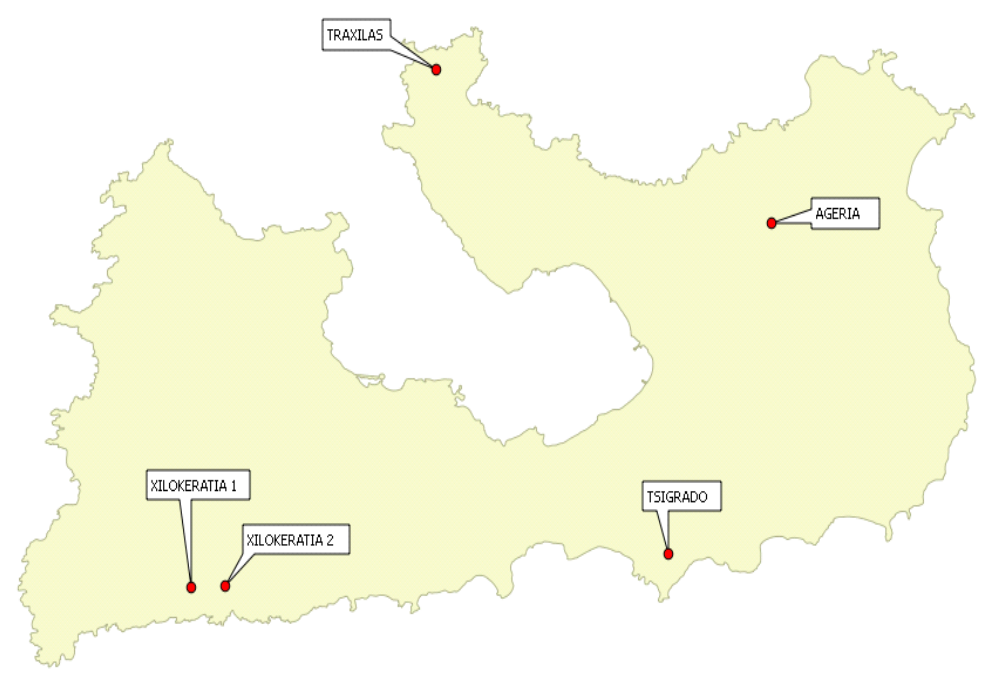

Figure 3: Quarries under consideration (unit $1 \mathrm{~cm}: 1 \mathrm{~km}$ ).

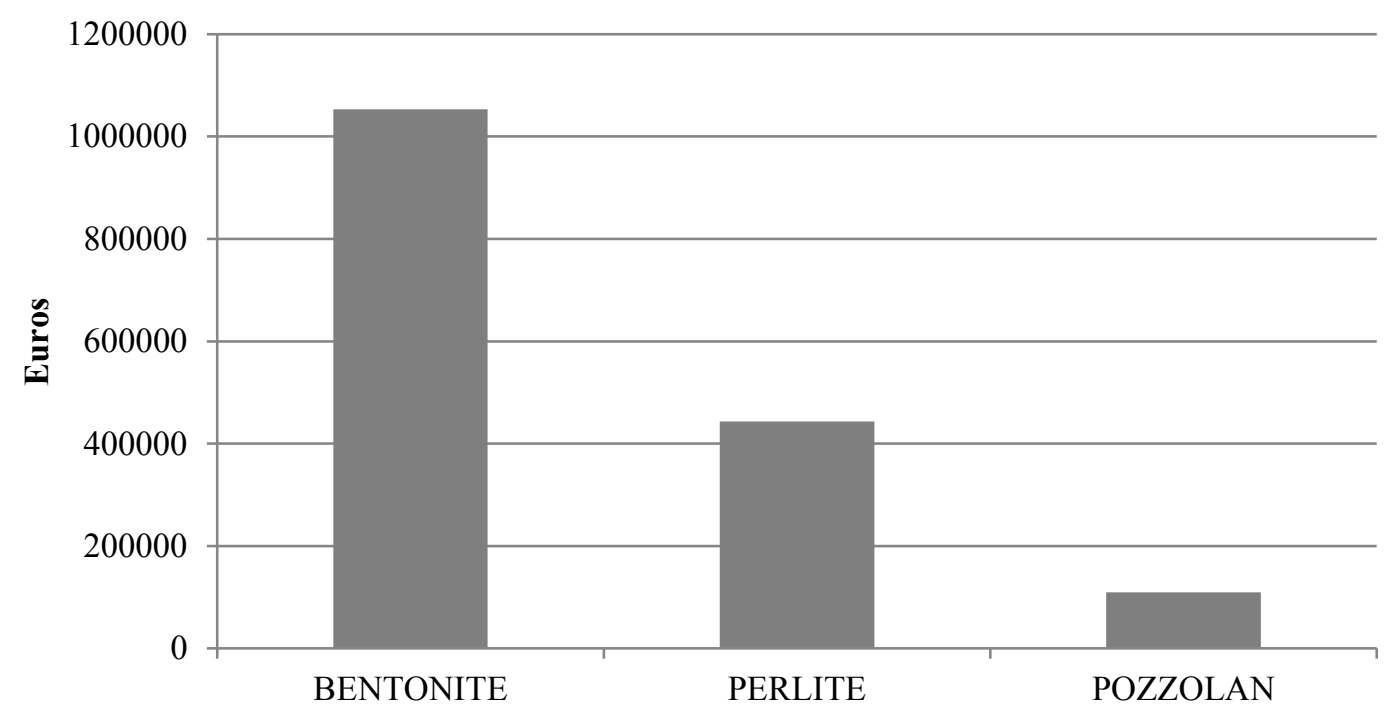

Figure 4. Market value of mineral per t. 


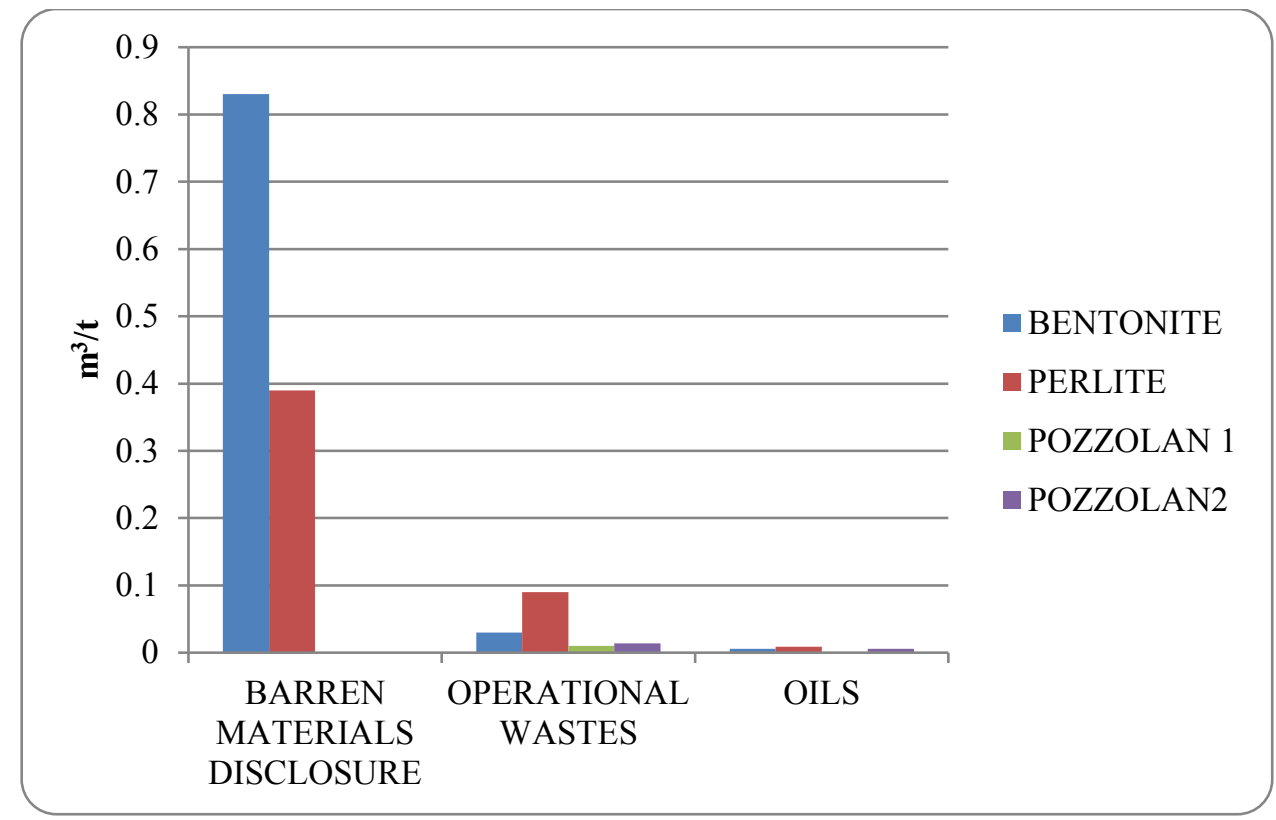

Figure 5. Waste production per category of industrial mineral.

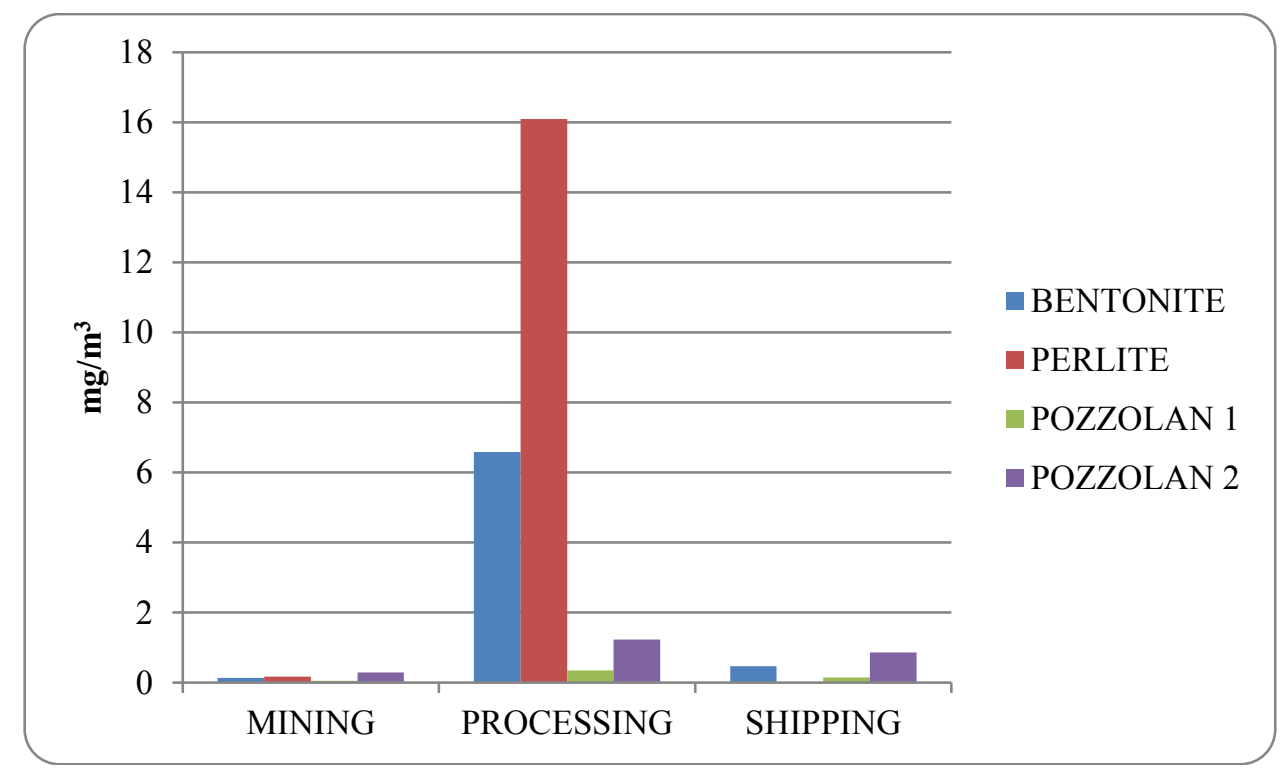

Figure 6. Dust concentrations per production process. 
Table 1. Bentonite production data for the years 2012-2014

\begin{tabular}{|c|c|c|c|c|c|c|}
\hline & & & Unit & 2012 & 2013 & 2014 \\
\hline Production & & & $\mathrm{t}$ & 1206219 & 978738 & 974510 \\
\hline \multirow{5}{*}{$\begin{array}{l}\text { Energy } \\
\text { consumption } \\
\text { per mining } \\
\text { steps }\end{array}$} & Mining & Oil & 1 & 1039128 & 998736 & 856606 \\
\hline & Transportation & Oil & 1 & 851206 & 883387 & 1026880 \\
\hline & \multirow[b]{2}{*}{$\begin{array}{l}\text { Milling (distribution) } \\
\text { and Storage }\end{array}$} & Mazut & $\mathrm{kg}$ & 7945000 & 7328000 & 7345000 \\
\hline & & $\begin{array}{l}\text { Electrical } \\
\text { powder }\end{array}$ & $\mathrm{kWh}$ & 6625600 & 5970450 & 5745000 \\
\hline & Loading to the ships & $\begin{array}{l}\text { Electrical } \\
\text { powder }\end{array}$ & $\mathrm{kWh}$ & 362260 & 328275 & 302890 \\
\hline \multirow{3}{*}{$\begin{array}{l}\text { Water } \\
\text { Consumption }\end{array}$} & From municipality & & $\mathrm{m}^{3}$ & 1711 & 1943 & 2811 \\
\hline & $\begin{array}{l}\text { From natural mining } \\
\text { bounds }\end{array}$ & & $\mathrm{m}^{3}$ & 38665 & 50524 & 54096 \\
\hline & Sea water & & $\mathrm{m}^{3}$ & 0 & 0 & 0 \\
\hline \multirow{6}{*}{$\begin{array}{l}\text { Waste } \\
\text { production }\end{array}$} & Sterile materials & & $\mathrm{m}^{3}$ & 873005 & 1100414 & 629828 \\
\hline & Batteries & & $\mathrm{kg}$ & 0 & 0 & 1117 \\
\hline & SCRAP & & $\mathrm{kg}$ & 94500 & 29400 & 55200 \\
\hline & Tires (track lories) & & $\mathrm{kg}$ & 77 & 1296 & 1272 \\
\hline & $\begin{array}{l}\text { Papers / paper } \\
\text { cardboard }\end{array}$ & & $\mathrm{kg}$ & 1405 & 1278 & 0 \\
\hline & $\begin{array}{l}\text { Oils from cars/engine } \\
\text { maintains }\end{array}$ & & $\mathrm{kg}$ & 3756 & 8220 & 6480 \\
\hline \multirow{7}{*}{$\begin{array}{l}\text { Air } \\
\text { emmissions }\end{array}$} & $\mathrm{O} 2$ & & $\%$ & 19.4 & 18.75 & 19.1 \\
\hline & $\mathrm{CO} 2$ & & $\%$ & 1.2 & 1.8 & 1.55 \\
\hline & $\mathrm{CO}$ & & $\mathrm{mg} / \mathrm{Nm}^{3}$ & 9.2 & 21.2 & 63.75 \\
\hline & $\mathrm{SO} 2$ & & $\mathrm{mg} / \mathrm{Nm}^{3}$ & 1.45 & 13.08 & 1.4 \\
\hline & $\mathrm{NO}$ & & $\mathrm{mg} / \mathrm{Nm}^{3}$ & 78.25 & 108.8 & 103.45 \\
\hline & NO2 & & $\mathrm{mg} / \mathrm{Nm}^{3}$ & 0.97 & 4.1 & 2.95 \\
\hline & NOX & & $\mathrm{mg} / \mathrm{Nm}^{3}$ & 79.2 & 112.9 & 106.35 \\
\hline \multirow{3}{*}{$\begin{array}{l}\text { Dust } \\
\text { concentration }\end{array}$} & Mining & & $\mathrm{mg} / \mathrm{m}^{3}$ & 0.14 & & \\
\hline & Milling (distribution) & & $\mathrm{mg} / \mathrm{m}^{3}$ & 1.45 & 9.11 & 9.2 \\
\hline & Loading to the ships & & $\mathrm{mg} / \mathrm{m}^{3}$ & 0.22 & 0.3 & 0.91 \\
\hline $\begin{array}{l}\text { Total } \\
\text { covered area }\end{array}$ & 800 hectares & & & & & \\
\hline
\end{tabular}


Table 2. Perlite production data for the years 2012-2014

\begin{tabular}{|c|c|c|c|c|c|c|}
\hline & & & Unit & 2012 & 2013 & 2014 \\
\hline Production & & & $\mathrm{t}$ & 468740 & 383301 & 479136 \\
\hline \multirow{5}{*}{$\begin{array}{l}\text { Energy } \\
\text { consumption } \\
\text { per mining } \\
\text { steps }\end{array}$} & Mining & Oil & 1 & 692753 & 665824 & 571072 \\
\hline & Transportation & Oil & 1 & 567471 & 588925 & 684588 \\
\hline & \multirow[b]{2}{*}{$\begin{array}{l}\text { Milling (distribution) } \\
\text { and Storage }\end{array}$} & Mazut & $\mathrm{kg}$ & 3345000 & 3125000 & 3350000 \\
\hline & & $\begin{array}{l}\text { Electrical } \\
\text { powder }\end{array}$ & $\mathrm{kWh}$ & 7490000 & 6442000 & 7120000 \\
\hline & Loading to the ships & $\begin{array}{l}\text { Electrical } \\
\text { powder }\end{array}$ & $\mathrm{kWh}$ & 241507 & 218851 & 201928 \\
\hline \multirow{3}{*}{$\begin{array}{l}\text { Water } \\
\text { Consumption }\end{array}$} & From municipality & & $\mathrm{m}^{3}$ & 1141 & 1296 & 1874 \\
\hline & $\begin{array}{l}\text { From natural mining } \\
\text { bounds }\end{array}$ & & $\mathrm{m}^{3}$ & 25777 & 33683 & 36064 \\
\hline & Sea water & & $\mathrm{m}^{3}$ & 0 & 678163 & 799228 \\
\hline \multirow{6}{*}{$\begin{array}{l}\text { Waste } \\
\text { production }\end{array}$} & Sterile materials & & $\mathrm{m}^{3}$ & 88387 & 219440 & 199551 \\
\hline & Batteries & & $\mathrm{kg}$ & 0 & 0 & 745 \\
\hline & SCRAP & & $\mathrm{kg}$ & 63000 & 19600 & 36800 \\
\hline & Tires (track lories) & & $\mathrm{kg}$ & 51 & 864 & 848 \\
\hline & $\begin{array}{l}\text { Papers / paper } \\
\text { cardboard }\end{array}$ & & $\mathrm{kg}$ & 938 & 852 & 0 \\
\hline & $\begin{array}{l}\text { Oils from cars/engine } \\
\text { maintains }\end{array}$ & & $\mathrm{kg}$ & 2504 & 5480 & 4320 \\
\hline \multirow{7}{*}{$\begin{array}{l}\text { Air } \\
\text { emmissions }\end{array}$} & $\mathrm{O} 2$ & & $\%$ & 17.5 & 17.65 & 19 \\
\hline & $\mathrm{CO} 2$ & & $\%$ & 2.6 & 2.55 & 1.4 \\
\hline & $\mathrm{CO}$ & & $\mathrm{mg} / \mathrm{Nm}^{3}$ & 7.05 & 34.55 & 28,3 \\
\hline & $\mathrm{SO} 2$ & & $\mathrm{mg} / \mathrm{Nm}^{3}$ & 0 & 1.3 & 1.25 \\
\hline & $\mathrm{NO}$ & & $\mathrm{mg} / \mathrm{Nm}^{3}$ & 190.6 & 125.8 & 64.05 \\
\hline & $\mathrm{NO} 2$ & & $\mathrm{mg} / \mathrm{Nm}^{3}$ & 8.45 & 4.85 & 1.9 \\
\hline & NOX & & $\mathrm{mg} / \mathrm{Nm}^{3}$ & 199.05 & 130.7 & 66 \\
\hline \multirow{2}{*}{$\begin{array}{l}\text { Dust } \\
\text { concentration }\end{array}$} & Mining & & $\mathrm{mg} / \mathrm{m}^{3}$ & 27.64 & 7.69 & 12.94 \\
\hline & Milling (distribution) & & $\mathrm{mg} / \mathrm{m}^{3}$ & 0.17 & & \\
\hline $\begin{array}{l}\text { Total } \\
\text { covered area }\end{array}$ & 470 hectares & & & & & \\
\hline
\end{tabular}


Table 3. Pozzolan type 1

\begin{tabular}{|c|c|c|c|c|c|c|}
\hline & & & Unit & 2012 & 2013 & 2014 \\
\hline Production & & & $\mathrm{t}$ & 139000 & 189000 & 136000 \\
\hline \multirow{3}{*}{$\begin{array}{l}\text { Energy } \\
\text { consumption per } \\
\text { mining steps }\end{array}$} & Mining & Explosive & $\mathrm{kg}$ & 0 & 0 & 3700 \\
\hline & $\begin{array}{l}\text { Mining and internal } \\
\text { Transportation }\end{array}$ & Oil & 1 & 106283 & 114283 & 101424 \\
\hline & $\begin{array}{l}\text { Milling } \\
\text { (distribution), } \\
\text { Storage, loading }\end{array}$ & $\begin{array}{l}\text { Electrical } \\
\text { powder }\end{array}$ & $\mathrm{kWh}$ & 130706 & 145317 & 120718 \\
\hline \multirow[t]{4}{*}{ Waste production } & Batteries & & $\mathrm{kg}$ & 680 & & \\
\hline & $\begin{array}{l}\text { Papers / paper } \\
\text { cardboard }\end{array}$ & & $\mathrm{kg}$ & & 100 & 200 \\
\hline & $\begin{array}{l}\text { Oils from } \\
\text { cars/engine } \\
\text { maintains } \\
\end{array}$ & & $\mathrm{kg}$ & 270 & & \\
\hline & Municipal waste & & $\mathrm{kg}$ & & 3000 & 2000 \\
\hline \multirow{3}{*}{$\begin{array}{l}\text { Air emissions } \\
\text { (total emissions) }\end{array}$} & Mining & & $\mathrm{mg} / \mathrm{m}^{3}$ & 0.05 & 0.05 & 0.05 \\
\hline & $\begin{array}{l}\text { Mining and internal } \\
\text { Transportation }\end{array}$ & & $\mathrm{mg} / \mathrm{m}^{3}$ & 0.35 & 0.35 & 0.35 \\
\hline & $\begin{array}{l}\text { Milling } \\
\text { (distribution), } \\
\text { Storage, loading }\end{array}$ & & $\mathrm{mg} / \mathrm{m}^{3}$ & 0.15 & 0.15 & 0.15 \\
\hline Total covered area & 440 hectares & & & & & \\
\hline
\end{tabular}


Table 4. Pozzolan type 2

\begin{tabular}{|c|c|c|c|c|c|c|}
\hline & & & Unit & 2012 & 2013 & 2014 \\
\hline Production & & & $\mathrm{t}$ & 40378 & 32120 & 42870 \\
\hline \multirow{2}{*}{$\begin{array}{l}\text { Energy } \\
\text { consumption per } \\
\text { mining steps }\end{array}$} & $\begin{array}{l}\text { Mining and internal } \\
\text { Transportation }\end{array}$ & Oil & $1 / \mathrm{t}$ & 0.9 & 0.87 & 0.83 \\
\hline & $\begin{array}{l}\text { Milling } \\
\text { (distribution), } \\
\text { Storage, loading }\end{array}$ & $\begin{array}{l}\text { Electrical } \\
\text { powder }\end{array}$ & $\mathrm{kWh} / \mathrm{t}$ & 0.76 & 0.82 & 0.71 \\
\hline \multirow[t]{2}{*}{ Waste production } & $\begin{array}{l}\text { Oils from } \\
\text { cars/engine } \\
\text { maintains }\end{array}$ & & $\mathrm{kg}$ & 0 & 609 & 0 \\
\hline & Other waste & & $\mathrm{kg}$ & 571 & 513 & 509 \\
\hline \multirow[t]{3}{*}{$\begin{array}{l}\text { Air emissions } \\
\text { (total emissions) }\end{array}$} & $\begin{array}{l}\text { Mining (mainly } \\
\text { dust) }\end{array}$ & & $\mathrm{mg} / \mathrm{m}^{3}$ & 0.29 & 0.29 & 0.29 \\
\hline & Milling process & & $\mathrm{mg} / \mathrm{m}^{3}$ & 1.23 & 1.23 & 1.23 \\
\hline & Loading & & $\mathrm{mg} / \mathrm{m}^{3}$ & 0.86 & 0.86 & 0.86 \\
\hline Total covered area & 350 hectares & & & & & \\
\hline
\end{tabular}

